\title{
Floral Origin and Physical and Chemical Characteristics of Honey from Africanized Bees in Apiaries of Ubiratã and Nova Aurora, State of Paraná
}

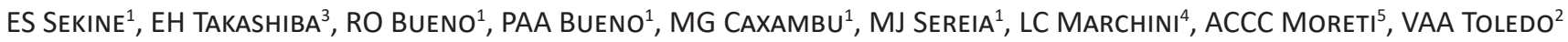 \\ 1 - Universidade Tecnológica Federal do Paraná - UTFPR, Campo Mourão-PR, Brazil \\ 2 - Universidade Estadual de Maringá - UEM, Maringá-PR, Brazil \\ 3 - Universidade Federal de Santa Maria - UFSM, Santa Maria-RS, Brazil \\ 4 - Escola Superior de Agricultura Luiz de Queiroz - Esalq/USP, Piracicaba-SP, Brazil \\ 5 - Instituto de Zootecnia, Nova Odessa-SP, Brazil
}

\section{Article History \\ Edited by \\ Eduardo Almeida, USP, Brazil \\ Received 27 April 2018 \\ Initial acceptance 16 July 2018 \\ Final acceptance 14 December 2018 \\ Publication date 25 April 2019}

\section{Keywords}

Apis mellifera; honey composition; physical and chemical parameters;.

\section{Corresponding author \\ ES Sekine}

Departamento de Biodiversidade e

Conservação da Natureza (DABIC)

Universidade Tecnológica Federal do Paraná

Via Rosalina Maria dos Santos no 1233, CP: 271

CEP: 87301-899 - Campo Mourão-PR, Brasil.

E-Mail: essekine@gmail.com

\begin{abstract}
Physical and chemical characteristics of honey may vary due to the diversity of flora and soil characteristics, or seasonal factors. This study was carried out in two counties, Nova Aurora and Ubiratã, located in the West and Center-West regions of the State of Paraná. The objective of the study was to verify if the physical and chemical parameters of Apis mellifera (L.) honey are in accordance with the national standard, as well as to verify how the 21 samples collected in the two localities are grouped, based on the physical, chemical and pollen characteristics. Honey was analyzed for sugar, ash, protein, moisture, color, electrical conductivity, formaldehyde index, diastase and viscosity, water activity and pollen content. Samples of honey containing the dominant pollen types Glycine max (L.) Merr. and Eucalyptus sp. formed groupings similar to those based on physical and chemical characteristics, however, the multivariate classification of honey samples in groups based on pollen types was not an efficient method to group samples of polyfloral honey.
\end{abstract}

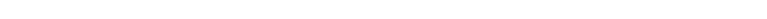

\section{Introduction}

Honey is a substance made mainly from the nectar of flowers, and because of the diversity of the Brazilian flora, it may present peculiarities in its physical and chemical characteristics, depending on the type of plant that is part of its composition. Different environments may lead to variations in honey characteristics due to floral species and soil characteristics, or due to seasonal factors such as temperature and rainfall (Crane, 1990; Marchini et al., 2004a).

Depending on the number of predominant floral species, honey may be classified as monofloral, bifloral or heterofloral. The latter, also called wild honey, has quite variable properties, depending on the environmental conditions and the type of flower used, and it is not possible to generalize its characteristics (Barth, 2004). For this reason, there is a need to compile data on the physical and chemical characteristics of honeys produced in the south and southeast regions of Brazil, as there are indications that the standards established in the Brazilian legislation (Brasil, 2000) do not include all these honeys (Barth et al., 2005).

As the characteristics of honey depend on the species available for the supply of nectar, investigations aimed at identifying the plants used by bees in different regions of the country provide information that can be used in the management of hives and in the adoption of strategies for a better utilization of the flora with potential for honey production (Marchini et al., 2004a; Nogueira Couto \& Couto, 2006). 
Several studies have been carried out in the southern and southeastern Brazil to investigate the floral origin of honey (Bosco \& Luz, 2017; Sekine et al., 2013) and its physicochemical characteristics (Mendonça et al., 2008; Sereia et al., 2011; Barth et al., 2013; Alves et al., 2011). This study aimed to analyze the floral origin, physical and chemical characteristics of samples of honey collected in two counties of Paraná state at different times of the year and to verify whether physicochemical characteristics are grouped depending on the floral species used in honey production.

\section{Material and methods}

\section{Obtaining samples of honey}

Honey samples were collected in two apiaries (Fig 1): Apiary A, located in the county of Nova Aurora, State

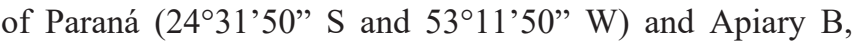
located in the county of Ubiratã, State of Paraná (24'29'41" $\mathrm{S}$ and $\left.53^{\circ} 02^{\prime} 43^{\prime \prime} \mathrm{W}\right)$. These counties are located in the phytogeographical domain of submontane semidecidous tropical forest (IBGE, 2012). In both properties, beekeeping is an activity complementary to the family income, so the area surrounding the apiaries is occupied by agriculture and the properties have a forest fragment as legal reserve area of 13.65 ha and 2.39 ha for apiaries $\mathrm{A}$ and $\mathrm{B}$, respectively

In order to obtain the honey samples, three hives were randomly marked in each apiary. All hives were located near or inside the forest fragments. In each hive, we placed every month a frame with new bee-wax foundation without combs, or (when available) a frame with formed combs to obtain the honey produced by the bees during the period. Inspection of hives was performed monthly to verify the existence of mature honey. To avoid sampling immature honey, honeycombs, with at least $75 \%$ of capped cells, were removed and centrifuged separately, in individual plastic bags, avoiding the honey mixture. After each harvest, the frames were replaced with other empty ones. The samples were transported to the laboratory in thermal boxes and kept under refrigeration for approximately six months.

A total of 21 samples were taken for the two apiaries (nine from apiary A and 12 from apiary B) between December 2008 and May 2009. In April and May there was no mature honey in apiary A.

\section{Physical and chemical analysis}

Physical and chemical analyses were performed in triplicate for each sample. Reducing sugars, total reducing sugars, sucrose, ash and protein were verified according to the methods adopted by the Adolfo Lutz Institute (Zenebon et al., 2008). The techniques used to determine the moisture content (Atago Co, 1988), color (Vidal \& Fregosi, 1984), electrical conductivity (BOE, 1986); $\mathrm{pH}$, acidity, formaldehyde index (Moraes \& Teixeira, 1998), diastase activity (C.A.C, 1990) and viscosity were done according to the methods cited by Marchini et al. (2004a). The water activity (Aw) determination was made directly using a water activity meter Aqualab®. The analyses were carried out at the Laboratory of Useful Insects of the Department of Entomology and Acarology of the School of Agriculture, Luiz de Queiroz-Esalq/USP and at the Chemistry and Ecosystems laboratories of the Federal Technological University of Paraná - UTFPR Campo Mourão.

\section{Pollen analysis}

An aliquot of $10 \mathrm{~g}$ of each sample was diluted in distilled water and centrifuged for acetolysis (Erdtman, 1952). The pollen analyses were: a) qualitative, by the identification of the pollen types by comparison with the collection of pollen slides of the plants collected in the region, and specialized literature; and b) quantitative, by the average count of 300 to 500 pollen grains on microscopy slides, in triplicate. Pollen types were

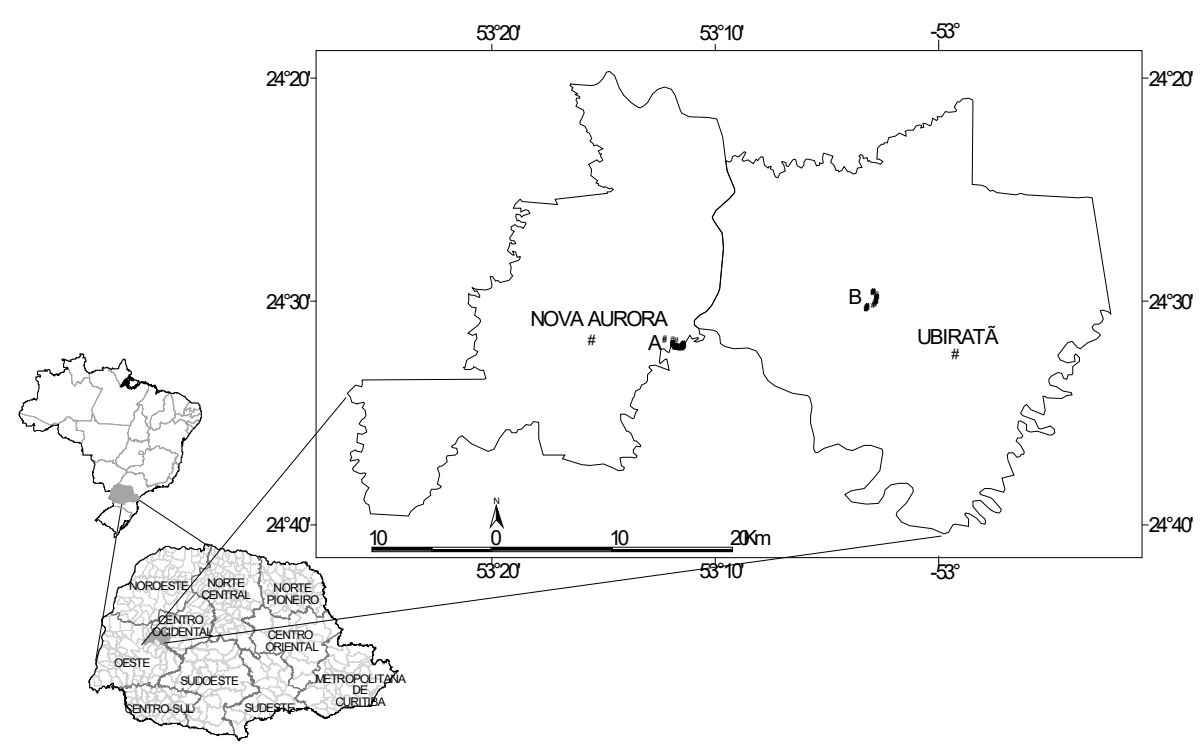

Fig 1. Location of the sampling sites. A: Apiary in Nova Aurora; B: Apiary in Ubiratã, State of Paraná. 
classified into four frequency classes (Louveaux et al., 1978; Barth, 1989): Dominant pollen (frequency over 45\%), Accessory pollen (from 16 to $45 \%$ ), Important isolated pollen (from 3 to $15 \%$ ), Occasional isolated pollen (frequency below $3 \%$ ).

\section{Data analysis}

We applied qualitative and quantitative descriptive statistical analysis and multivariate statistical analysis: clustering technique for the honey samples, using the statistical software R (2016). For the pollen data of the two areas, we calculated the Sorensen Similarity Index (ISS) (Legendre \& Legendre, 1984; Mueller-Dombois \& Ellenberg, 1974; Pielou, 1975), which is the most commonly used to compare qualitative floristic data between communities. Mathematically, the index is defined as: ISS $=2 c /(a+b+c) \times 100$, where: $a=$ number of species restricted to area $a, b=$ number of species restricted to area $\mathrm{b}$ and $\mathrm{c}=$ number of species common to areas $a$ and $b$.

The results of the physical and chemical analyses of honey were compared between the sampling sites by clustering analysis using the Euclidean distance by the UPGMA clustering method. In the cluster analysis, the mean Euclidean distances for the properly standardized data were adopted as dissimilarity means. The clustering based on the pollen types found in honey was made from the presence and absence of pollen types using the Jaccard coefficient by the UPGMA linkage method using the vegan package (Oksanen, 2017) using the statistical software R. Jaccard coefficient expresses the similarity between honey samples, based on the number of common pollen types.

\section{Results}

\section{Physical and chemical characteristics}

There was predominance of the extra-light amber color (50\%). Light amber (27\%) and white $(23 \%)$ were also found in honey samples. The complete results of the physical and chemical parameters analyzed are listed in Table 1.

The parameters that have limits established by the Brazilian legislation (diastase, moisture, $\mathrm{pH}$, acidity, reducing sugars, sucrose and ash) (Brasil, 2000) were met in the samples collected (Table 1). Only one of the samples contained moisture above the established values.

\section{Pollen analysis}

In the honey samples, we identified 49 pollen types belonging to 25 families (Table 2). Two pollen types were not identified at the family level. The pollen types with higher frequency belong to the families Fabaceae (34.9\%), Myrtaceae (11.7\%) and Piperaceae (11.4\%) (Figure 2A).
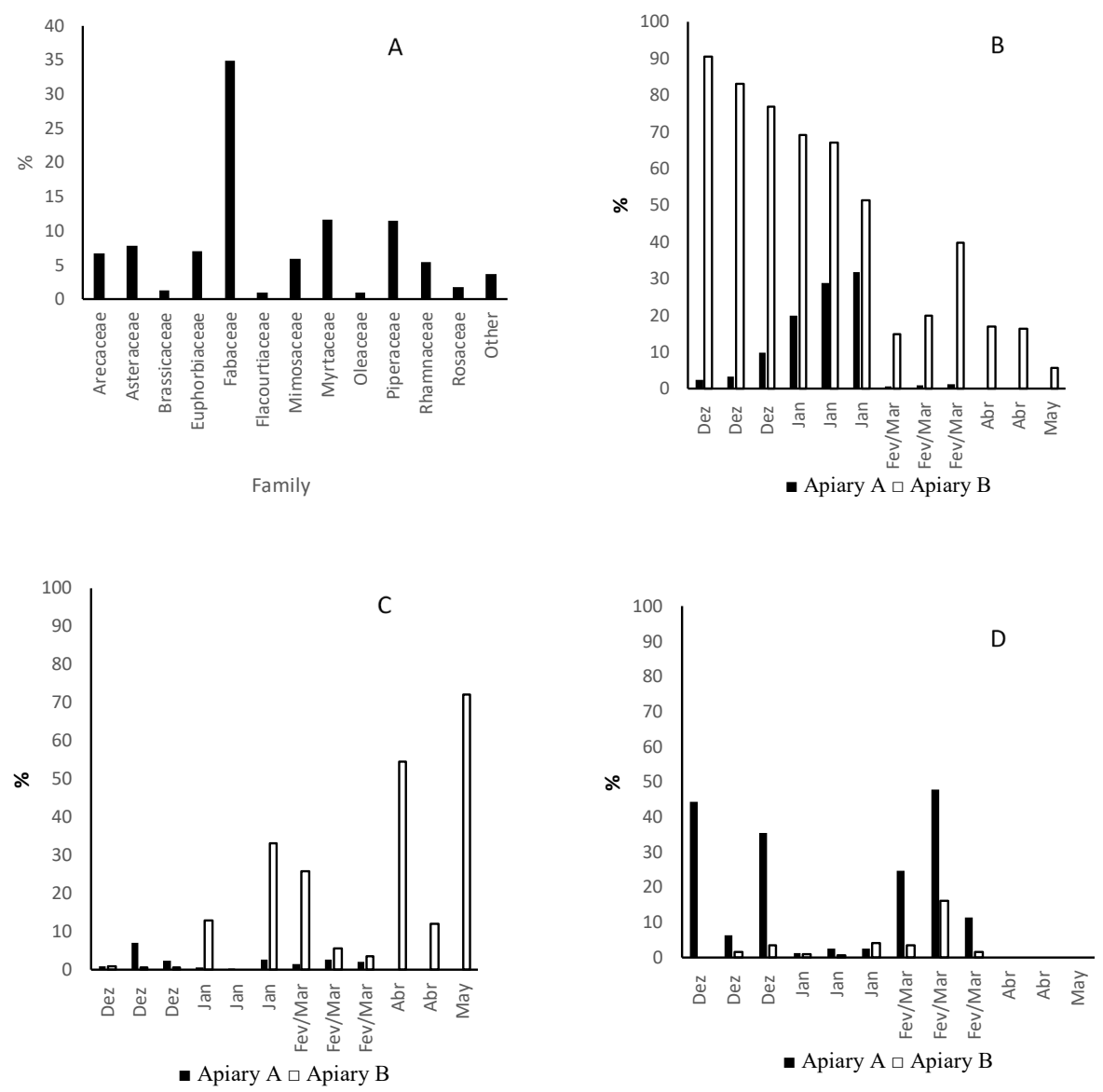

Fig 2. Pollen types frequency in honey samples from two apiaries in the counties of Ubiratã and Nova Aurora in the Paraná state, Brazil. A) Frequency of the main families found in honey in the two apiaries; B, C and D, pollen frequency of the dominant species found in the two apiaries from December 2008 to May 2009, respectively, Glycine max, Eucalyptus spp., and Piperaceae type. 
สำ

๘

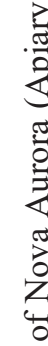

疍

¿

.

ڤे

胥

$\stackrel{\infty}{8}$

离

๑ั

号

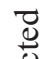

$\stackrel{0}{\circ}$

㐫

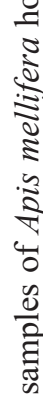

$\overrightarrow{\mathrm{T}}$

峁

营

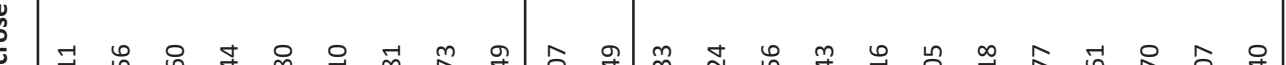

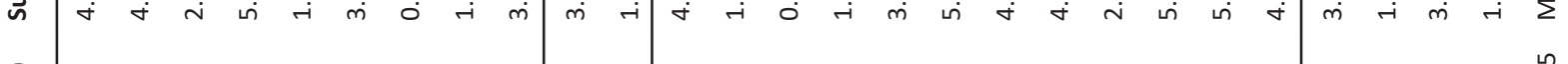

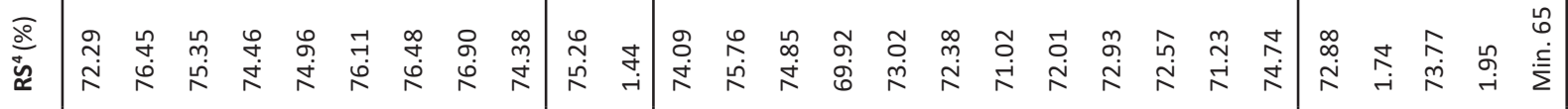

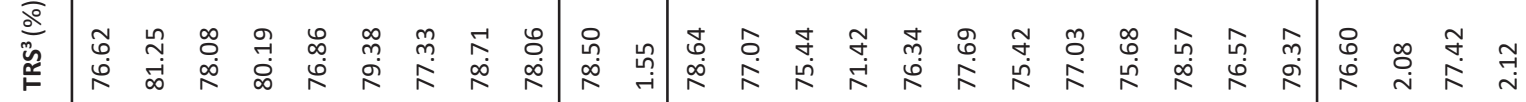

茪

ص

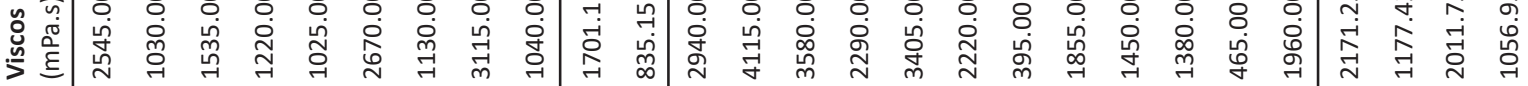

委

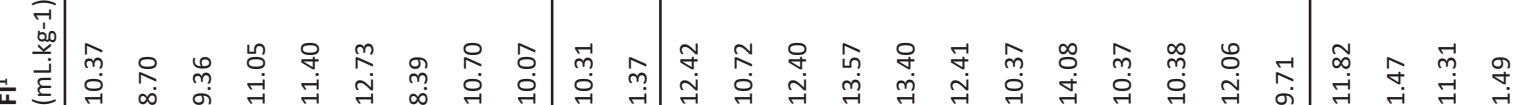

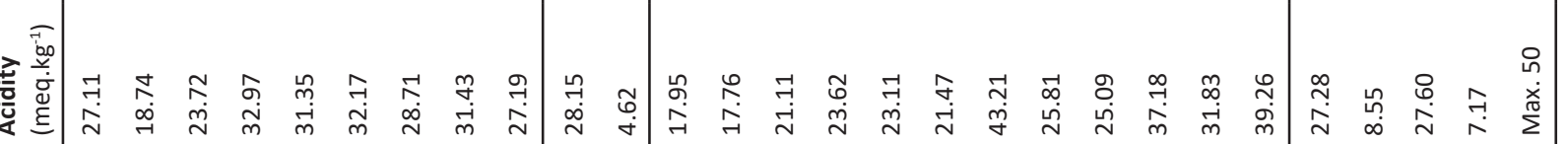

ㅇำ

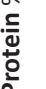

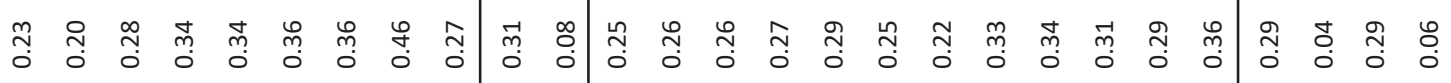

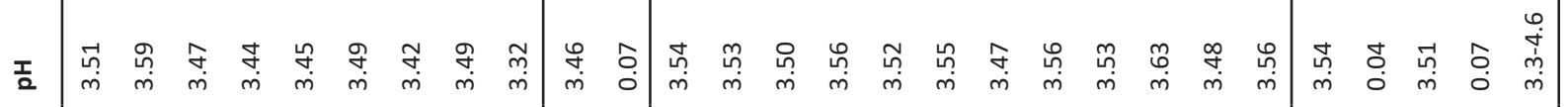

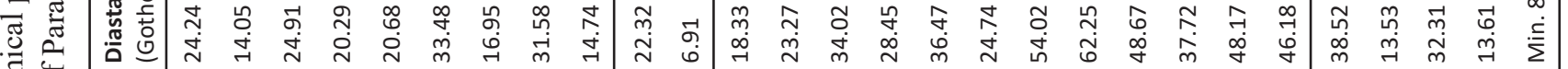

苟

吾宅

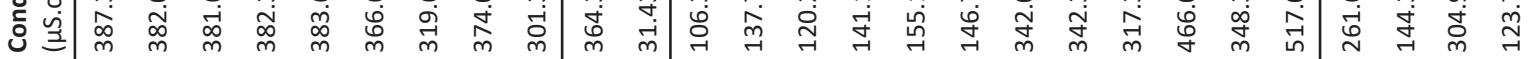
이 귀 
The families with the highest number of pollen types represented were Asteraceae (seven), Euphorbiaceae, Mimosaceae and Myrtaceae (four types each).

Dominating pollen types (D) were found in several of the samples collected in apiary B, with Glycine max (soybean) in the months of December and January, with frequencies between $51.4 \%$ and $90.6 \%$. and Eucalyptus spp. in the months of April (54.7\%) and May (72.2\%). In apiary A, the pollen of Piperaceae was dominant $(47.8 \%$ ) in February (Figure 2B, C, D). Soybean pollen was also found as accessory pollen in seven other samples, Piperaceae in four and Eucalyptus in two samples. Also found as accessory pollen, in at least one sample, pollen types of the genera Baccharis, Mikania, Lonchocarpus and Campomanesia and the species Alchornea triplinervea (Spreng.) Müll.Arg. Parapiptadenia rigida (Benth.) Brenan (Mimosaceae) appeared in all samples, but its contribution never reached more than $10 \%$ of the total of a sample. Samples 5 and 7, both of apiary A, had higher number of pollen types (17).

Important isolated pollen (I) totaled 80 occurrences, from 30 pollen types. Occasional isolated pollen $(\mathrm{O})$ had 175 occurrences, from 50 pollen types. The similarity between the areas, measured from the pollen types present in the samples of honey, was $87 \%$.

\section{Cluster analysis}

Cluster analysis based on the physical and chemical characteristics (Figure 3A), showed two groups, evidencing the collection sites. One group consists mainly of samples of apiary A with four samples of apiary B, and the other group consisted mainly of samples of apiary B and only three samples of apiary A. The dendrogram formed by the pollen types presented high similarity (Figure 3B), showing samples from the same site and month of collection, except for sample $\mathrm{B} 19$ and B21.

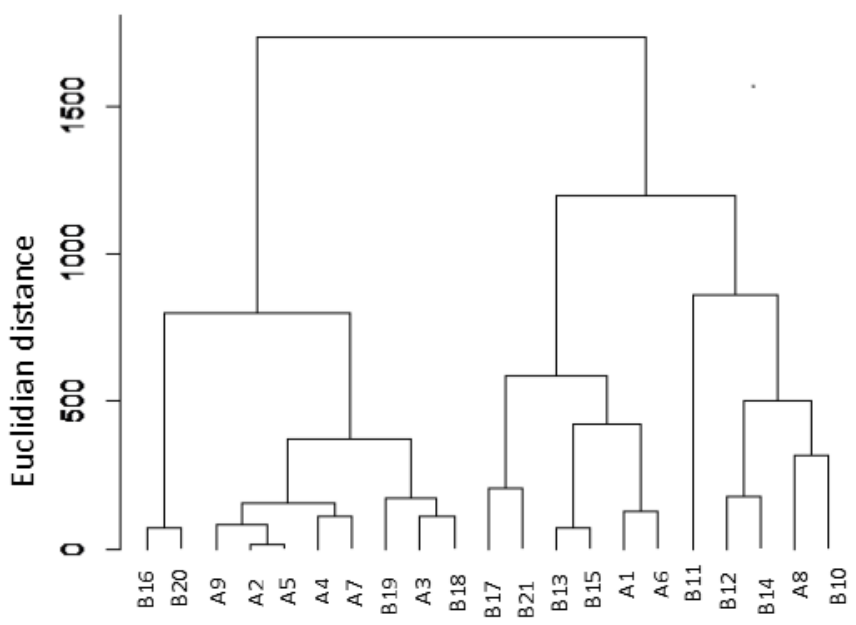

Honey sample

\section{Discussion}

The color of the honey samples indicates the presence of mineral content (Bath \& Singh, 1999; Finola et al., 2007). Wild or polyfloral honey tends to exhibit a large color variation (Almeida-Anacleto \& Marchini, 2004). The samples analyzed here have a light color. In general, honey with light color has higher market value (Boffo et al., 2012; Silva et al., 2013; Almeida-Muradian et al., 2014).

Samples are within the ranges established in the Brazilian legislation for all analyzed parameters. Only one exceeded the maximum allowed for moisture $(21.4 \%)$. The high moisture content is verified in honey harvested when the alveoli were not completely sealed. Additionally, relative air humidity may also contribute to moisture in honey (Faria, 1993; Sereia et al., 2011). Despite the care in collecting the samples with $75 \%$ of the alveoli covered, this sample had higher humidity. Values lower than $18.5 \%$ usually indicate mature honey (Marchini et al., 2004b). Honey from partially capped cells often presents a high percentage of moisture (Sanz et al., 1995). The stability of honey with moisture between 17 and 20\% depends on a low content of microorganisms (Malacalza et al., 2007).

Some parameters limited by Brazilian legislation are indicative of honey quality. Among them, the diastase index refers to alpha-amylase, the enzyme responsible for the digestion of starch. Its origin is attributed to the salivary secretion of bees and is a parameter that gives indications of overheating. However, this is not always true because some types of honey naturally have less diastase than others, once the enzyme is added by the bees during the ripening of the nectar to the thicker consistency of honey. As some types of nectar are naturally thicker than others, they require less processing by the bee and, consequently, less diastase (White, 1994). The percentage of ash in honey expresses the content of mineral material, being a parameter widely used to check honey

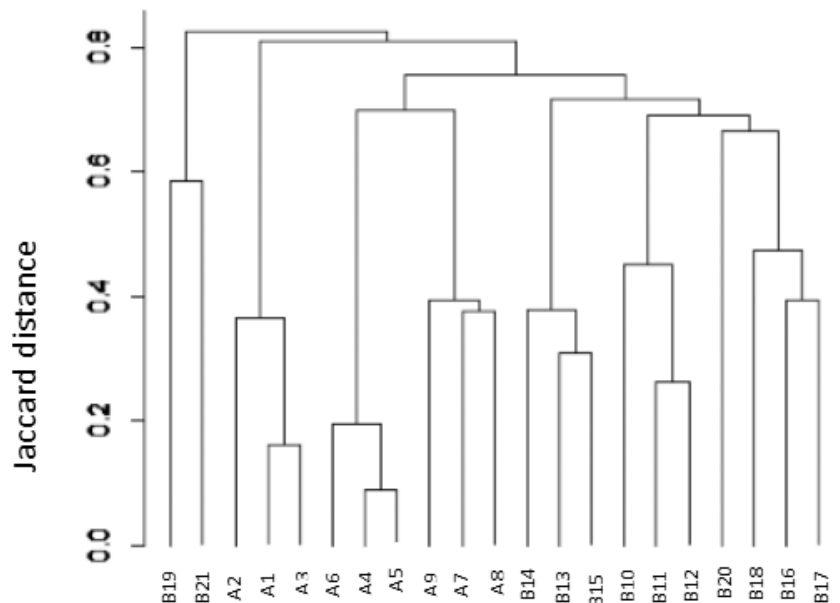

Honey sample

Fig 3. Clusters obtained by the UPGMA method - A) Euclidean distance from physical and chemical characteristics and B) Jaccard method from the pollen types. Analyses made on samples of Apis mellifera honey, collected from December 2008 to May 2009, in the counties of Nova Aurora and Ubiratã, State of Paraná. 
quality (Marchini et al., 2005). Acidity is also an important component of honey, as it contributes to its stability, against the development of microorganisms (Marchini et al., 2004b).

Brazilian legislation establishes a minimum of $65 \%$ of reducing sugars and a maximum of $6 \%$ of sucrose (Brasil, $2000)$. In general, fructose and glucose account for about $80 \%$ of the total sugar content in honey, while sucrose and maltose represent about $10 \%$. The balance of the different types of sugars results in differences in honey, such as viscosity, density and crystallization (White, 1975). However, the proportion of sugars may vary according to the botanical origin (Nozal et al., 2005; De-Melo et al., 2017; Manzanares et al., 2017).

With respect to the parameters not covered by the Brazilian legislation, the percentage of protein can be used to detect honey adulteration, with $0.26 \%$ being the average value of the international standard (Almeida-Anacleto \& Marchini, 2004). However higher values were found in samples from different sources, reaching 1-2\% (Rebane \& Herodes 2008; DeMelo et al., 2017). The electrical conductivity is a parameter that can be used to determine the origin of honey (Aganin, 1971) and is related to botanical origin, mineral content, $\mathrm{pH}$, acidity, proteins and other substances present in honey (White Jr, 1975; Bogdanov, 1999). The electrical conductivity ranged from 106.33 to $517 \mu \mathrm{S} . \mathrm{cm}-1$ in the presente study. Higher values have been recorded in honey from different locations (Sodré et al., 2003; Sodré et al., 2007; Almeida-Anacleto \& Marchini; Marchini et al., 2005; Mendonça et al., 2008; Alves et al., 2011). Similar or lower values were also found (Arruda et al., 2005; Sereia et al., 2011). The values obtained for the formalin index ranged from 8.70 to $14.08 \mathrm{~mL} . \mathrm{kg}-1$. These values are similar to other studies (Marchini et al., 2005; Mendonça et al., 2008; Sodré et al., 2003; Almeida-Anacleto \& Marchini, 2004; Alves et al., 2011).

Viscosity and water activity also have no values established in Brazilian legislation. The viscosity is mainly influenced by the percentage of water and the fructose and glucose ratio, honey with higher fructose content has lower viscosity, and also depends on temperature and floral origin. (Fattori, 2004). In the present study viscosity values were between 395 and 4115, with the highest values observed in honeys with dominant pollen types Glycine max and Piperaceae. The values of water activity are between 0.54 and 0.65 , with an average of $0.60 \pm 0.03$. Under aerobic conditions, the inhibitory water activity is aw $=0.86$, and substrates with aw $=0.6$ are assured of microbial deterioration (AlmeidaAnacleto, 2004). In general, the results of the physical and chemical parameters are quite variable between samples from different regions which makes difficult to establish a pattern related to the parameters not covered by the legislation.

Considering the pollen types present in the samples, the families Asteraceae, Euphorbiaceae, Mimosaceae and Myrtaceae were also frequent in other studies in the southern and southeastern regions, with similar vegetation (Sereia et al., 2011; Araujo et al., 2013; Bosco \& Luz, 2017).
The studied region is soybean producer $(G$. max $)$ and six samples had this species as dominant pollen type. The two counties are located in agricultural areas, and the main crops are corn and soybeans. The genus Eucalyptus was present in many samples. The contribution of species of this genus as dominant pollen in honey samples was verified in other studies in the southeast region (Bastos et al., 2003; Sodré et al., 2003; Barth et al., 2005; Luz et al., 2007; Mendonça et al., 2008; Silveira et al., 2012; Araujo et al., 2013; Barth et al., 2013). The increase of this pollen type in honey samples can be explained by the increase of reforested areas with species of Eucalyptus.

In the study area, it was verified that there are four species of Eucalyptus, three that bloom between January and April and one that blooms in November. Soybean flowering in the region occurs in the months of November, December and March (Sekine et al., 2013). Samples with these dominant pollen types were verified only in apiary $\mathrm{B}$, which has smaller forested area. In apiary A, which has a larger forest remnant, polyfloral honey samples were collected. Despite the predominance of agricultural crops in both properties, pollen analysis results reflect the greater diversity of this environment.

The high similarity of pollen types shown in the dendrogram was expected, since the two apiaries belong to the same phytogeographic region at natural restoration stage. Samples from apiary A, A1 and A3, contained Piperaceae spp. as accessory pollen, and sample A2, Lonchocarpus sp. and Campomanesia spp. also as accessory pollen. Samples A4, A5 and A6 had as accessory pollen Arecaceae spp. and $G$. max. Samples A7, A8 and A9 had in common several species, including Piperaceae as dominant, accessory or important isolated pollen and Acacia and P. rigida as important isolated pollen in the three samples. From apiary B, samples B19 and B21, had Eucalyptus spp. as dominant pollen. Samples B10 to $\mathrm{B} 15$ had in common G. max as dominant pollen and B17 to B20 G. $\max$ as accessory pollen.

Comparing the two dendrograms, it was observed that the clusters were not coincident, which shows that polyfloral honey samples are quite variable for physical and chemical characteristics. However, samples of the apiary B containing dominant pollen Glycine max and Piperaceae are grouped and present the highest values of viscosity and lower conductivity.

Marchini et al. (2004b) observed the influence of accessory and dominant pollen types on the physical and chemical characteristics of honey samples in the State of Tocantins. In samples from the State of São Paulo, it was also verified the grouping of physical and chemical characteristics in Eucalyptus honey and wild honey (Marchini et al., 2005). In another study also in São Paulo state, it was verified the grouping of monofloral samples of orange, but the Eucalyptus samples were distributed in several different groups (Marchini et al., 2007). It was also verified the grouping of physical and chemical characteristics in Moroccan unifloral honeys of Eucalyptus, Citrus and honeydew (Terrab et al., 2003). 
Table 2. Pollen spectrum and frequency classes in 21 samples of Apis mellifera honey collected at two locations in the counties of Nova Aurora (Apiário A) and Ubiratã (Apiário B) from December 2008 to May 2009.

\begin{tabular}{|c|c|c|c|c|c|c|c|c|c|c|c|c|c|c|c|c|c|c|c|c|c|c|}
\hline \multirow{3}{*}{ Family } & \multirow{3}{*}{ Pollen type } & \multicolumn{9}{|c|}{ APIARY A } & \multicolumn{12}{|c|}{ APIARY B } \\
\hline & & \multicolumn{3}{|c|}{ Dec } & \multicolumn{3}{|c|}{ Jan } & \multicolumn{3}{|c|}{ Feb/Mar } & \multicolumn{3}{|c|}{ Dec } & \multicolumn{3}{|c|}{ Jan } & \multicolumn{3}{|c|}{ Feb/Mar } & \multicolumn{2}{|c|}{ Apr } & \multirow{2}{*}{$\frac{\text { May }}{21}$} \\
\hline & & 1 & 2 & 3 & 4 & 5 & 6 & 7 & 8 & 9 & 10 & 11 & 12 & 13 & 14 & 15 & 16 & 17 & 18 & 19 & 20 & \\
\hline \multirow[b]{2}{*}{ Anacardiaceae } & Mangifera indica & & & & & & & & & & & & & & & & & & & & & $\mathrm{O}$ \\
\hline & $\begin{array}{l}\text { Schinus } \\
\text { terebinthifolius }\end{array}$ & & & & & & & & & & & & $\mathrm{O}$ & 1 & $\mathrm{O}$ & $\mathrm{O}$ & $\mathrm{O}$ & 1 & $\mathrm{O}$ & & & \\
\hline Arecaceae & Arecaceae type & & & & A & A & A & I & & A & & $\mathrm{O}$ & & $\mathrm{O}$ & 1 & & 1 & $\mathrm{O}$ & & 0 & 0 & $\mathrm{O}$ \\
\hline \multirow{7}{*}{ Asteraceae } & Baccharis spp. & & & & A & 1 & 1 & & & & & & & $\mathrm{O}$ & 1 & $\mathrm{O}$ & 1 & A & $\mathrm{O}$ & A & 1 & I \\
\hline & Bidens spp. & & & & & & & & & & & & & $\mathrm{O}$ & $\mathrm{O}$ & $\mathrm{O}$ & & & & & & \\
\hline & $\begin{array}{l}\text { Calyptocarpus } \\
\text { biaristatus }\end{array}$ & & & & & & & & & & & & & & & & $\mathrm{O}$ & $\mathrm{O}$ & & & & \\
\hline & $\begin{array}{l}\text { Chromolaena } \\
\text { pedunculosa }\end{array}$ & & & & & & & & & & & & & & & & & & & & & $\mathrm{O}$ \\
\hline & Conyza bonariensis & & & & 0 & $\mathrm{O}$ & $\mathrm{O}$ & & & & & & & & & & & & & & & \\
\hline & Mikania spp. & & & & & & & I & $\mathrm{O}$ & A & & & & & & & 1 & 1 & $\mathrm{O}$ & & & \\
\hline & Senecio brasiliensis & & & & & & & & & & & $\mathrm{O}$ & $\mathrm{O}$ & & & & & & & & & \\
\hline \multirow{2}{*}{ Boraginaceae } & Cordia ecalyculata & & & & 0 & $\mathrm{O}$ & $\mathrm{O}$ & & & & & & & & & & & & & & & \\
\hline & Cordia trichotoma & & & & & & & & & & & & & & & & & & & & & $\mathrm{O}$ \\
\hline Brassicaceae & Indeterminada spp. & & & & 1 & I & I & $\mathrm{O}$ & 0 & $\mathrm{O}$ & & & & & & & & & & & & \\
\hline Caesalpinaceae & Bauhinia forficata & & & & & & & & 1 & & & & & $\mathrm{O}$ & $\mathrm{O}$ & $\mathrm{O}$ & $\mathrm{O}$ & & & & & \\
\hline Combretaceae & $\begin{array}{l}\text { Combretum } \\
\text { fruticosum }\end{array}$ & & & & & $\mathrm{O}$ & 0 & & & & & & & $\mathrm{O}$ & & $\mathrm{O}$ & & & & & & \\
\hline \multirow{4}{*}{ Euphorbiaceae } & Alchornea triplinervea & A & 1 & I & & & & $\mathrm{O}$ & 0 & $\mathrm{O}$ & 1 & $\mathrm{O}$ & $\mathrm{O}$ & & $\mathrm{O}$ & $\mathrm{O}$ & $\mathrm{O}$ & $\mathrm{O}$ & & & & \\
\hline & Bernardia pulchela & & & & 0 & $\mathrm{O}$ & 1 & & & & & & & & & & & $\mathrm{O}$ & $\mathrm{O}$ & & & \\
\hline & Ricinus communis & $\mathrm{O}$ & & $\mathrm{O}$ & & & & & & & & & $\mathrm{O}$ & & & & & & & & & $\mathrm{O}$ \\
\hline & $\begin{array}{l}\text { Sebastiania } \\
\text { brasiliensis }\end{array}$ & & & & 1 & I & $\mathrm{O}$ & $\mathrm{O}$ & 0 & & & & & $\mathrm{O}$ & 1 & $\mathrm{O}$ & & & & & & \\
\hline \multirow{2}{*}{ Fabaceae } & Glicyne max & $\mathrm{O}$ & 1 & I & A & A & A & $\mathrm{O}$ & $\mathrm{O}$ & $\mathrm{O}$ & D & D & D & D & D & D & 1 & A & A & A & A & I \\
\hline & Lonchocarpus sp. & 1 & A & I & 1 & I & 1 & $\mathrm{O}$ & I & 1 & 0 & I & I & & & & I & $\mathrm{O}$ & 1 & & & \\
\hline Flacourtiaceae & Casearia sylvestris & $\mathrm{O}$ & 1 & $\mathrm{O}$ & 1 & 1 & $\mathrm{O}$ & & & & & & & & & & & & & & & \\
\hline \multirow{2}{*}{ Lamiaceae } & Hyptis mutabilis & & & & & & & $\mathrm{O}$ & $\mathrm{O}$ & & & & & & & & & & & & & \\
\hline & Leonurus sibiricus & $\mathrm{O}$ & 1 & $\mathrm{O}$ & & & & & & & & & & & & & & & & & & \\
\hline Malvaceae & $\begin{array}{l}\text { Wissadula } \\
\text { subpeltata }\end{array}$ & & & & & & & $\mathrm{O}$ & & & & & & & $\mathrm{O}$ & & & & & $\mathrm{O}$ & & $\mathrm{O}$ \\
\hline Meliaceae & Melia azedarach & $\mathrm{O}$ & 0 & $\mathrm{O}$ & & & & & & & & & & & & & & & & & & \\
\hline \multirow{4}{*}{ Mimosaceae } & Acacia type & & & & $\mathrm{O}$ & $\mathrm{O}$ & & I & I & 1 & $\mathrm{O}$ & $\mathrm{O}$ & $\mathrm{O}$ & & & & I & $\mathrm{O}$ & $\mathrm{O}$ & 0 & 1 & \\
\hline & $\begin{array}{l}\text { Leucaena } \\
\text { leucocephala }\end{array}$ & $\mathrm{O}$ & $\mathrm{O}$ & $\mathrm{O}$ & 0 & $\mathrm{O}$ & $\mathrm{O}$ & & & & & & & & & & & & & 0 & & \\
\hline & Mimosa sp. & & & & & & & & $\mathrm{O}$ & & & & & & & & & & & $\mathrm{O}$ & & \\
\hline & Parapiptadenia rigida & $\mathrm{O}$ & 1 & $\mathrm{O}$ & $\mathrm{O}$ & $\mathrm{O}$ & $\mathrm{O}$ & I & 1 & 1 & $\mathrm{O}$ & $\mathrm{O}$ & $\mathrm{O}$ & I & $\mathrm{O}$ & $\mathrm{O}$ & 1 & 1 & $\mathrm{O}$ & 0 & I & $\mathrm{O}$ \\
\hline & Campomanesia spp. & $\mathrm{O}$ & A & I & & & & & & & & & & & & & & & & & & \\
\hline Murtaceae & Eucalyptus spp. & $\mathrm{O}$ & 1 & $\mathrm{O}$ & $\mathrm{O}$ & $\mathrm{O}$ & $\mathrm{O}$ & $\mathrm{O}$ & 0 & $\mathrm{O}$ & 0 & $\mathrm{O}$ & $\mathrm{O}$ & I & & A & A & 1 & I & D & 1 & D \\
\hline & Hexaclamys edulis & $\mathrm{O}$ & 1 & I & & & & & & & & $\mathrm{O}$ & $\mathrm{O}$ & & & & & & & & & \\
\hline & Myrcia type & & & & & & & & & & & & & & & & & & & 1 & & \\
\hline
\end{tabular}


Table 2. Pollen spectrum and frequency classes in 21 samples of Apis mellifera honey collected at two locations in the counties of Nova Aurora (Apiário A) and Ubiratã (Apiário B) from December 2008 to May 2009. (Continuation)

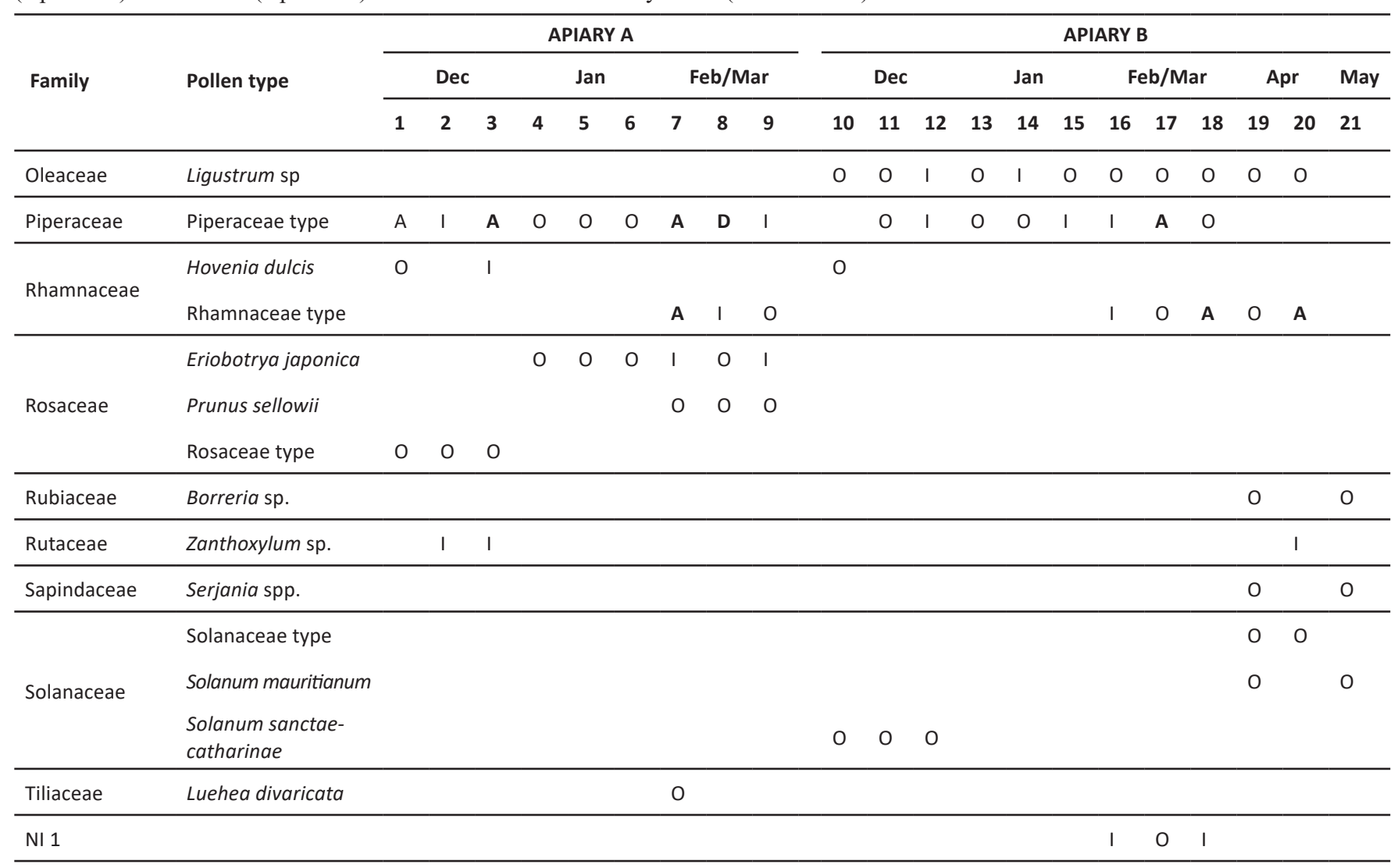

* $\mathrm{D}=$ dominant pollen $(>45,0 \%) ; \mathrm{A}=$ accessory pollen $(16,0$ a $45,0 \%) ; \mathrm{I}=$ important isolated pollen $(3,0$ a $15,0 \%)$;

$\mathrm{O}=$ occasional isolated pollen $(<3,0 \%)$. NI $=$ Not identified.

The geographic origin of the honey, collected in different localities with different types of vegetation can also influence the groupings of physical and chemical characteristics (Santos et al., 2008) which was not verified in the present study.

The similarities occurring in honey samples can be caused by the variability of floral species used in honey composition or due to the abiotic characteristics of the collection sites, which may influence the characteristics of the honey (Crane, 1990; Marchini et al., 2004b; Barth, 2004). The samples form clusters of physical-chemical and pollen similarities related to the collection sites. Samples of honey containing the dominant pollen G. max and Eucalyptus were grouped according to physical and chemical characteristics, which shows the influence of the pollen type on the characteristics of honey, when the floral species present high representativeness. However, multivariate classification in groups based on pollen types formed no clusters in samples of polyfloral honey.

\section{Acknowledgments}

The authors thank the beekeepers who made possible the collection of the samples used in this work.

\section{References}

Aganin, A.F. (1971). Electrical conductivity of several unifloral honeys. Trudy Saratovskogo Zootekhnicheskogo Instituta, 21: 137-144.

Almeida -Anacleto, D. \& Marchini L.C. (2004). Composição físico-química de amostras de méis Apis mellifera L. provenientes do cerrado paulista. Boletim de Indústria Animal, 61: 161-172.

Almeida-Muradian, L.B., Sousa, R.J, Barth, O.M., Gallmann, P. (2014). Preliminary data on brazilian monofloral honey from the northeast region using FT-IR ATR spectroscopic, palynological, and color analysis. Quimica Nova, 37: 716-719.

Alves, E.M., Sereia, M.J., Toledo, V.A.A., Marchini, L.C., Neves, C.A., Toledo, T.C.S.O.A, Almeida-Anacleto, D. (2011). Physicochemical characteristics of organic honey samples of africanized honeybees from Parana River islands. Ciência e Tecnologia de Alimentos, 31: 635-639.

Araujo, D.F.D., Moreti, A.C.C.C; Silveira, T.A., Marchini, L.C. \& Otsuk, I.P. (2013). Pollen Content in Honey of Apis mellifera Linnaeus (Hymenoptera, Apidae) in an Atlantic 
Forest Fragment in the Municipality of Piracicaba, São Paulo State, Brazil. Sociobiology, 60: 436-440. doi: 10.13102/ sociobiology.v60i4.436-440

Arruda, C.M.F., Marchini, L.C., Moreti, A.C., Otsuk, I.P. \& Sodré, G.S. (2005). Características físico-químicas de méis da Chapada do Araripe/Santana do Cariri-Ceará. Acta Scientiarum Animal Sciences, 27: 171-176.

Atago Co LTDA. (1988). Refratômetro para mel. Abelhas, 31: 9-44.

Barth, O.M. (1989). O pólen no mel brasileiro. Rio de Janeiro: Luxor, 150p.

Barth, O.M. (2004). Melissopalynology in Brazil: a review of pollen analysis of honeys, própolis and pollen loads of bees. Scientia Agricola, 61: 342-350.

Barth, O.M., Freitas, A.S., Sousa, G.L., Almeida-Muradian, L.G. (2013). Pollen And physicochemical analysis of Apis and Tetragonisca (Apidae) honey. Interciencia, 38: 280-285.

Barth, O.M., Maiorino, C., Benatti, A.P.T. \& Bastos, D.H.M. (2005). Determinação de parâmetros físico-químicos e da origem botânica de méis indicados monoflorais do sudeste do Brasil. Ciência e Tecnologia de Alimentos, 25: 229-233.

Bastos, E.M.A.F., Silveira, V.M. \& Soares, A.E.E. (2003). Pollen spectrum of honey produced in Cerrado areas of Minas Gerais state. Brazilian Journal of Biology, 63: 599-615.

Bath, P.K. \& Singh, N. (1999). A comparison between Helianthus annuus and Eucalyptus lanceolatus honey. Food Chemistry, 67: 389-397.

Boe. (1986). Orden de 12 de junio de 1986, de la Presidencia del Gobierno por la que se aprueban los métodos oficiales de análisis para la miel. Boletin Oficial Español, 145: 22195-22202.

Boffo, E.F., Tavares, L.A., Tobias, A.C.T., Ferreira, M., Ferreira, A.G. (2012). Identification of componentes of Brazilian honey by H NMR and classification of its botanical origin by chemometric methods. Food Science and Technology, 49: 55-63

Bogdanov, S. (1999). Honey quality and internacional regulatory standards: review by the International Honey Commission. Bee world, 80: 61-69.

Bosco, L.B. \& Luz, C.F.P. (2017). Pollen analysis of Atlantic forest honey from the Vale do Ribeira Region, state of São Paulo, Brazil. Grana, 57: 144-157. doi: 10.10 80/001731 34.2017.1319414

Brasil - Ministério da Agricultura, Pecuária e Abastecimento. (2000). Instrução Normativa 11, de 20 de outubro de 2000, Regulamento Técnico de identidade e qualidade do mel. Available at: http://www.agricultura.gov.br/sda/dipoa/anexo_ intrnorm11.htm.

CAC - Codex Alimentarius Commission. (1990). Official methods of analysis. Rome. V.3, supl.2, p.15-39.
Crane, E. (1990). Bees and beekeeping: science, practice and world resources. Oxford: Heinemann Newnes, 614p.

De-Melo, A.A.M., Almeida-Muradian, L.B., Sancho, M.T. \& Pascual-Maté, A. (2017). Composition and properties of Apis mellifera honey: A review. Journal of Apicultural Research, 57: 5-37.

Erdtman, G. (1952). Pollen morphology and plant taxonomyAngiosperms. Stockholm: Almqvist e Wiksel, 539 p.

Faria, J.A.F. (1993). Shelf life testing of honey. Ciência e Tecnologia de Alimentos, 13: 58-66.

Fattori, S.B. (2004). La miel: propiedades, composición y análisis físico-químico [Honey: Properties, composition and physicochemical analysis]. Buenos Aires: Comisión Apimondia "Tecnología y Productos".

Finola, M.S., Lasagno, M.C. \& Marioli, J.M. (2007). Microbiological and chemical characterization of honeys from central Argentina. Food Chemistry, 100: 1649-1653.

Ibge - Instituto Brasileiro de Geografia e Estatística. (2012). Manual Técnico da Vegetação Brasileira: Sistema fitogeográfico; Inventário das formações florestais e campestres; Técnicas e manejo de coleções botânicas; Procedimentos para mapeamentos. Manuais Técnicos em Geociências, n 1. 2 ed. Rio de Janeiro. 275p

Legendre, L. \& Legendre, P. (1984). Ecologie numérique. 2. ed. Paris: Masson, 335p.

Louveaux, J., Maurizio, A. \& Vorwohl, G. (1978). Methods of melissopalynology. Bee World, 59: 139-157.

Luz, C.F.P., Thomé, M.L. \& Barth, O.M. (2007). Recursos tróficos de Apis mellifera L. (Hymenoptera, Apidae) na região de MorroAzul do Tinguá, Estado do Rio de Janeiro. Revista Brasileira de Botânica, 30: 29-36,

Malacalza, N.H., Mouteira, M.C., Baldi, B. \& Lupano, C.E. (2007). Characterisation of honey from different regions of the Province of Bueno Aires, Argentina. Journal of Apicultural Research, 46: 8-14.

Manzanares, A.B., García, Z.H., Galdón, B.R., RodríguezRodríguez, E.M. \& Romero, C.D. (2017). Physicochemical characteristics and pollen spectrum of monofloral hoys from Tenerife, Spain. Food Chemistry, 228: 441-446. doi: 10.10 16/j.foodchem.2017.01.150

Marchini, L.C., Moreti, A.C. \& Otsuk, I.P. (2005). Análise de agrupamento, com base na composição físico-química de amostras de méis produzidos por Apis mellifera L. do Estado de São Paulo. Ciência e Tecnologia de Alimentos, 25: 8-17.

Marchini, L.C., Moretti, A.C., Otsuki I.P. \& Sodré, G. (2007). Physicochemical composition of Apis mellifera honey samples from São Paulo state, Brazil. Quimica Nova, 30: 1653-1657.

Marchini, L.C., Sodré, G.S. \& Moreti, A.C. (2004a). Mel brasileiro: composição e normas. Ribeirão Preto: A.S. Pinto, 111p. 
Marchini, L.C., Sodré, G.S., Moreti, A.C. \& Otsuk, I.P. (2004b). Composição físico-química de amostras de méis de Apis mellifera L. do Estado de Tocantis, Brasil. Boletim de Indústria Animal, 61: 101-114.

Mendonça, K., Marchini, L.C., Souza, B.A., Almeida-Anacleto, D. \& Moreti, A.C. (2008). Caracterização físico-química de amostras de méis produzidas por Apis mellifera L. em fragmento de cerrado no município de Itirapina, São Paulo. Ciência Rural, 38: 1748-1753.

Moraes, R.M. \& Teixeira, E.W. (1998). Analise de Mel (Manual Técnico). Pindamonhangaba: Centro de apicultura tropical, IZ/SAA, 41p.

Mueller-Dumbois, D. \& Ellenberg, H. (1974). Aims and methods of vegetation ecology, New York: John Willey, 547p.

Nogueira Couto, R.H. \& Couto L.A. (2006). Apicultura: manejo e produtos. 3 ed., Jaboticabal: FUNEP, 193 p.

Nozal, M.J., Bernal, J.L., Toribio, L., Alamo, M., Diego, J.C., \& Tapia, J. (2005). The use of carbohydrate profiles and chemometrics in the characterization of natural honeys of identical geographical origin. Journal of Agricultural and Food Chemistry, 53: 3095-3100.

Oksanen, J., Blanchet, F.G., Friendly, M., Kindt, R., Legendre, P., Mcglinn, D., Minchin, P.R., O'hara, R.B., Simpson, G.L., Solymos, P., Stevens, M.H.H., Szoecs, E. \& Wagner, H. (2017). Vegan: community ecology package. R package version, 2.4-2. Available at: https://CRAN.R-project.org/package=vegan. (Accessed 02 April 2018).

Pielou, E.C. (1975). Ecological diversity. New York: John Willey, 165p.

R Core Team. (2016). R: A language and environment for statistical computing. R Foundation for Statistical Computing, Vienna, Austria. Available at: https://www.R-project.org/.

Rebane, R., Herodes, K. (2008). Evaluation of the Botanical Origin of Estonian Uni and Polyfloral Honeys by Amino Acid Content. Journal of Agricultural and Food Chemistry, 56: 10716-10720.

Santos, J. S., Santos, N.S., Santos, M.L.P., Santos, S.N. and Lacerda, J.J.J. Honey Classification from Semi-Arid, Atlantic and Transitional Forest Zones in Bahia, Brazil. Journal of the Brazilian Chemical Society, 2008(19): 502-508.

Sanz, S., Gradillas, G., Jimeno, F., Perez, C. \& Juna, T. (1995). Fermentation Problem in Spanish North-Coast Honey. Journal of Food Protection, 58: 515-518.

Sekine, E.S.; Toledo, V.A.A.; Caxambu, M.G.; Chmura, S. Takashiba, E.H.; Sereia, M.J.; Marchini, L.C.; Moreti,
A.C.C.C. (2013). Melliferous flora and pollen characterization of honey samples of Apis mellifera L., 1758 in apiaries in the counties of Ubiratã and Nova Aurora, PR. Anais da Academia Brasileira de Ciências. 85: 307-326. doi: 10.1590/S000137652013005000017

Sereia, J.A., Alves, E.M., Toledo, V.A.A., Marchini, L.C., Sekine, E.S., Faquinello, P., Almeida, D. \& Moreti, A.C. (2011). Physicochemical characteristics of organic honeys of africanized honeybees from Paraná River islands. Anais da Academia Brasileira de Ciências 83: 1077-1090. doi: 10.1590/S0001-37652011000300026.

Silva, A.S., Alves, C.N., Fernandes, K.G., Müllerd, R.C.S. (2013). Classification of honeys from Pará state (Amazon region, Brazil) produced by three different species of bees using chemometric methods. Journal of the Brazilian Chemical Society, 24: 1135-1145.

Silveira, T.A., Correia-oliveira, M.E, Moreti, A.C.C.C., Otsuk, I.P. \& Marchini, L.C. (2012). Botanical Origin of Protein Sources Used by Honeybees (Apis mellifera) in an Atlantic Forest. Sociobiology, 59: 1-10

Sodré, G.S., Marchini, L.C., Moreti, A.C. \& Carvalho, C.A.L. (2003). Análises multivariadas com base nas características físico-químicas de amostras de méis de Apis mellifera L. (Hymenoptera: Apidae) da região litoral norte no estado da Bahia. Archivos Latinoamericanos de Producción Animal, 11: $129-137$.

Sodré, G.S., Marchini, L.C., Moreti, A.C. Otsuk, I.P. \& Carvalho, C.A.L. (2007). Caracterização físico-química de amostras de méis de Apis mellifera L. (Hymenoptera: Apidae) do Estado do Ceará. Ciência Rural, 37: 1139-1144.

Terrab, A., González, A.G., Díez, M.J., Heredia, F.J., (2003). Characterisation of Moroccan unifloral honeys using multivariate analysis. European Food Research and Technology, 218: 88-95.

Vidal, R. \& Fregosi, E.V. (1984). Mel: características, análises físico-químicas, adulteração e transformação. Barretos: Instituto Tecnológico Científico Roberto Rios.

White Jr, J.W. (1975). Physical characteristics of honey. In CRANEE. Honey a comprehensive survey, London: Heinemann, p.207-239.

White Jr, J.W. (1994). The role of hmf and diastase assays in honey quality evaluation. Bee World, 75: 104-117.

Zenebon, O., Pascuet, N.S. \& Tiglea, P. (2008). Procedimentos e determinações gerais. In: Métodos físico-químicos para análise de alimentos. 4 ed. São Paulo: Instituto Adolfo Lutz, Cap. 4, p. 125-130. 